\title{
The influence of fruit and vegetable intake on the nutritional status and plasma homocysteine levels of institutionalised elderly people
}

\author{
LM Bermejo ${ }^{1}$, A Aparicio $^{1}$, P Andrés $^{2}$, AM López-Sobaler ${ }^{1}$ and RM Ortega ${ }^{1, *}$ \\ 'Departamento de Nutrición, Facultad de Farmacia, Universidad Complutense, E-28040 Madrid, Spain: \\ ${ }^{2}$ Laboratorio de Técnicas Instrumentales. Sección Departamental de Química Analítica, Facultad de Farmacia, \\ Universidad Complutense, 28040-Madrid, Spain
}

Submitted 7 November 2005: Accepted 26 July 2006

\begin{abstract}
Objective: To determine the difference in the nutritional status of elderly people depending on their consumption of fruits and vegetables, and to study the possible association between the consumption of these foods and different cardiovascular risk factors, especially total plasma homocysteine (t-Hcys) levels.

Design, setting and subjects: A cross-sectional study in 152 institutionalised older people from Madrid aged $\geq 65$ years. Food and nutrient intakes were recorded over 7 days using the 'precise individual weighing' method. The weight, height, and waist and hip circumferences of all subjects were recorded, as were their $\alpha$-erythrocyte glutathione reductase, serum $\mathrm{B}_{6}, \mathrm{~B}_{12}$ and folate levels, erythrocyte folate levels, t-Hcys levels, serum lipids and blood pressure. The experimental population was then divided into tertiles depending on the serving intake of fruit and vegetables (T1, $<2.29$ servings day ${ }^{-1}$; T2, 2.29-2.79 servings day ${ }^{-1}$; and $\mathrm{T} 3,>2.79$ servings day $^{-1}$ ). Results: Compared with T1 subjects, T3 subjects showed consumptions of cereals, pulses, meat, fish and eggs closer to those recommended $(P<0.05)$. In addition, the contribution of their diet towards covering the recommended daily intake of vitamin $\mathrm{B}_{1}$, niacin, vitamin $\mathrm{B}_{6}$, folic acid, vitamin $\mathrm{C}, \mathrm{B}_{12}$, vitamin $\mathrm{A}$, and $\mathrm{P}, \mathrm{Mg}, \mathrm{Zn}$ and Fe was higher. The intake of fibre increased with consumption of fruit and vegetables $(r=0.6839, P<0.001)$. T3 subjects also had better serum and erythrocyte folate levels than T1 and T2 subjects $(P<0.05)$. A positive correlation was found between the consumption of fruit and vegetables and serum folate $(r=0.2665, P<0.01)$ and with erythrocyte folate levels $(r=0.2034, P<0.05)$, and a negative correlation with t-Hcys $(r=-0.2493, P<0.01)$.

Conclusions: Greater consumption of fruit and vegetables is associated with better food habits, increased vitamin and mineral intakes and lower t-Hcys levels. Considering that the fruit and vegetable intake in Spanish elderly people is very low, it is recommended that the consumption of fruits and vegetables by elderly people be increased.
\end{abstract}

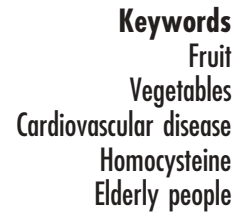

Cardiovascular disease (CVD) is one of the main causes of death in the developed world ${ }^{1}$ and, although its aetiololgy is multifactorial, diet plays a major role in its appearance ${ }^{2}$.

High total plasma homocysteine (t-Hcys) levels have been identified as a risk factor for $\mathrm{CVD}^{3}$. There is evidence to suggest that vitamins $\mathrm{B}_{2}, \mathrm{~B}_{6}$ and $\mathrm{B}_{12}$ might reduce $\mathrm{t}-\mathrm{HCys}$ since, like folic acid, they act as cofactors for the enzymes that break it down ${ }^{4,5}$. Indeed, t-Hcys levels are negatively correlated with serum and erythrocyte folate levels ${ }^{6,7}$.

Diets rich in fruits and vegetables may help reduce the risk of CVD via a number of beneficial effects, for example through the displacement from the diet of foods high in sodium and fats, as well as high-energy foods. These foods are also important sources of fibre and sterols, which reduce serum low-density lipoprotein (LDL)-cholesterol and total cholesterol levels ${ }^{8}$, and reduce blood pressure (by being low in sodium) ${ }^{9}$. In addition, the high antioxidant content of fruit and vegetables helps improve endothelial function ${ }^{10}$ and, together with legumes, these foods are the main source of folate ${ }^{11}$.

Many studies (the majority of which were performed on adult populations) have shown an association between low fruit and vegetable intake and the development of CVD and other degenerative diseases ${ }^{12}$. As people become older they eat less food (and therefore consume fewer fruit and vegetables), their lifestyles become more sedentary and their energy expenditure falls. This exposes the ageing population to nutritional deficits and malnutrition (especially with respect to trace elements), increasing their risk of developing $\mathrm{CVD}^{13}$. 
The aim of the present work was to assess the differences in the nutritional status of elderly people with respect to their consumption of fruit and vegetables, and to study the possible association between the intake of these foods and cardiovascular risk factors, especially t-Hcys levels.

\section{Methods}

\section{Study population}

The study subjects were 152 people (all $\geq 65$ years of age; $64 \%$ women, $36 \%$ men) from three homes for the elderly in the Madrid region of Spain. These centres were chosen from an original total of 15 randomly selected centres in the area. Six of these centres declined the offer to participate, and another three had insufficient residents. The directors, medical staff and kitchen staff of the remaining six were contacted for information on the residents' medical backgrounds, mental health scores and the medications they took. This allowed three centres to be chosen with sufficient residents of similar characteristics and who were in an acceptable physical and mental condition. The meals of all three centres were prepared by the same catering service.

Subjects who had any of the following were excluded: all those with a disease that might affect digestion, absorption or use of nutrients (neoplasms, cirrhosis, abnormal liver function, poor intestinal absorption, etc.); and those who took medications that might interfere with their appetite or any of the measured variables. After informing the subjects of the characteristics of the study, their written consent to be included was requested in line with the ethical requirements of the Faculty of Pharmacy Research Committee.

\section{Dietetic study}

All food and drink consumed over 7 days was recorded using the 'precise individual weighing' method ${ }^{14}$. Data were recorded under the same conditions at all three centres, i.e. by the same persons, in the same way, starting on the same day of the week and using the same equipment. A 'food record' was also kept by all subjects in order to register all consumptions outside set meal times (e.g. food brought to them by family members, food bought at the centres' cafeterias and food purchased outside the centres). Data were provided by the subjects themselves.

Once the consumption of food was known $\left(\mathrm{g} \mathrm{day}^{-1}\right)$, the number of servings of each food was calculated. Each food (g) was divided into the average sized servings established for the Spanish population ${ }^{15}$. The average size considered for fruit was $100-150 \mathrm{~g}$, and for vegetables $150-200 \mathrm{~g}$. The population was then divided into tertiles corresponding to the daily consumption of fruits and vegetables: the first tertile (T1) ate $<2.29$ servings day ${ }^{-1}$, the second (T2) ate $2.29-2.79$ servings day ${ }^{-1}$ and the third (T3) ate more than this.

The energy and nutrient contents of the food and drink consumed by each subject were calculated using the food composition tables of the Instituto de Nutrición (1994) ${ }^{16}$, as completed by Moreiras et $a l^{17}$. To assess the adequacy of the diet, the subjects' nutrient intakes were compared with the 'Recommended Intakes of Energy and Nutrients for the Spanish Population, ${ }^{18}$. The recommended intake of fibre $^{19}$ was established as $25 \mathrm{~g} \mathrm{day}^{-1}$.

The energy expenditure was estimated using equations proposed by the World Health Organization (WHO) in $1985^{20}$ for the calculation of the basal metabolic rate, and then multiplying by an activity coefficient appropriate for each subject. To establish these coefficients, each subject completed a questionnaire (adapted from that of Dallosso et $a l^{21}$ for elderly persons) that collected information on the number of hours spent involved in typical daily activities, e.g. walking, eating, standing, reading and sleeping. The discrepancy between the energy intake and estimated energy expenditure was calculated using the equation ${ }^{22}$ : (energy expenditure-energy intake) $\times 100$ /energy expenditure. When the final value is negative, this probably indicates that the energy intake is greater than the estimated energy expenditure, and thus the subject probably overestimated his/her intake. When the final value is positive, the energy intake is less than the energy expenditure, and the subject has underestimated his/her intake ${ }^{22}$.

\section{Antbropometric study}

Height and weight were measured using a Seca Alpha digital electronic balance (range $0.1-150 \mathrm{~kg}$ ) and a Harpenden digital stadiometer (range $70-205 \mathrm{~cm}$ ), respectively. Hip and waist circumferences were measured using a flexible, metallic measuring tape (Holtain) (range 0$150 \mathrm{~cm}$ ). All measurements were performed by trained personnel with the subjects barefoot and wearing only underwear, following the international norms recommended by $\mathrm{WHO}^{23}$. These data were used to calculate the body mass index $\left(\mathrm{kg} \mathrm{m}^{-2}\right)$ and the waist-to-hip ratio.

\section{Biochemical study}

Blood samples were taken from 146 subjects either in the infirmary of each centre or in their rooms. All extractions, performed first thing in the morning after a minimum $12 \mathrm{~h}$ nocturnal fast, were made by venous puncture in the antecubital fossa. The collected blood was distributed into different tubes: one with heparin - to determine the number of erythrocytes and vitamin $\mathrm{B}_{2}$ status; two with no anticoagulant - to obtain serum and to determine vitamin $\mathrm{B}_{6}$, serum folate, cyanocobalamin and lipid levels; and one with ethylenediaminetetraacetic acid - to determine the erythrocyte folate and t-Hcys levels. All tubes were kept at 4$6^{\circ} \mathrm{C}$ until analysis, which was always preformed within $48 \mathrm{~h}$.

Vitamin $\mathrm{B}_{2}$ status was determined by measuring the activation of erythrocyte glutathione reductase (EGR) by 
flavine adenine dinucleotide (FAD). The activity of the enzyme was measured by spectrophotometry in baseline conditions and after the addition of excess FAD from haemolysed blood samples. The relationship between enzyme activity before and after saturation is expressed by the saturation coefficient $\alpha$. High $\alpha$-coefficients imply an unfavourable biochemical riboflavin status (coefficient of variation $(\mathrm{CV})=4.4 \%)^{24}$.

Serum vitamin $\mathrm{B}_{6}$ levels were determined by highpressure liquid chromatography (HPLC), using a semicarbazone pre-column and fluorescence detection $(\mathrm{CV}=3.1 \%)^{25}$.

Serum folate $(\mathrm{CV}=4.5 \%)$, erythrocyte folate $(\mathrm{CV}=4.9 \%)$ and serum vitamin $\mathrm{B}_{12}(\mathrm{CV}=3.2 \%)$ were determined by radioimmunoassay using the Vitamin B12/Folate Dual Radioassay Kit (Diagnostic Products Corporation). A gamma counter model 1612 (Nuclear Enterprises Ltd) was used to quantify the signals emitted ${ }^{26}$.

Triglycerides were determined by GPO/PAP enzymatic hydrolysis (Merck 19706, CV $=3.2 \%)^{27}$, and total cholesterol $(\mathrm{CV}=3.2 \%)$ and high-density lipoprotein (HDL)cholesterol $(\mathrm{CV}=3.2 \%)$ by an enzymatic-colorimetric technique after precipitation in serum with phosphowolframic acid and magnesium ions ${ }^{28}$. LDL-cholesterol was estimated using the Friedewald equations ${ }^{29}$. VLDLcholesterol $=$ triglycerides $/ 5$ and LDL-cholesterol $=$ total cholesterol - (VLDL-cholesterol + HDL-cholesterol), where $\mathrm{VLDL}=$ very-low-density lipoprotein.

Plasma homocysteine levels were determined by HPLC ${ }^{30}$ $(\mathrm{CV}=6.5 \%)$. Separation was achieved with an RP-18 column (Symta) using an intelligent pump (Merck-Hitachi L-6200 A; Hitachi). Detection was performed by fluorescence spectrophotometry. All reagents were supplied by Merck.

\section{Health study}

All diseases suffered by the subjects and the medications they took were recorded. Blood pressure was measured following the recommendations of Frohlich et l $^{31}$.

\section{Statistical analysis}

All data were processed using RSIGMA BABEL 2000 software (Horus Hardward). Means and standard deviations were calculated for all variables. One-way analysis of variance was used to determine the differences between groups. Differences between proportions were determined using the $\chi^{2}$ test. A number of correlation coefficients were also recorded. The Newman-Keuls test was used for detailed comparisons of the three tertile groups. Analysis of covariance (ANCOVA) was used to determine the interaction between variables. Significance was set at $P<0.05$.

\section{Results}

The mean age of the subjects was 82 years; no significant differences in age were seen with respect to sex. The mean daily consumption of fruit and vegetables was $2.95 \pm 0.92$ servings day ${ }^{-1}$, again with no significant differences between the sexes. No significant differences were seen in the general characteristics of the three tertile groups (Table 1).

The mean discrepancy between the energy intake and theoretical energy expenditure was $-0.21 \pm 17.78$, but this fell as the consumption of fruit and vegetables increased $(r=-0.2789, P<0.001)$. The dietary data were therefore corrected by ANCOVA.

Table 2 shows that the T3 subjects had a smaller difference between their true and recommended intakes of servings of cereals, legumes, meat, fish and eggs than did T1 subjects $(P<0.05)$. In addition, a positive correlation was seen between fruit and vegetable consumption and the number of servings of legumes $(r=0.2701, P<0.001)$, meat, fish and eggs $(r=0.5214$, $P<0.001)$ and nuts $(r=0.1884, P<0.05)$ consumed; a negative correlation was found with the consumption of sweet foods $\left(\mathrm{g} \mathrm{day}^{-1}\right)(r=-0.1749, P<0.05)$. These correlations were maintained when the discrepancy

Table 1 General and anthropometric characteristics of the study population divided into tertiles with respect to the consumption of fruits and vegetables (mean $\pm \mathrm{SD})$

\begin{tabular}{|c|c|c|c|c|}
\hline & \multicolumn{3}{|c|}{ Tertiles } & \multirow[b]{2}{*}{ ANOVA } \\
\hline & T1 & T2 & T3 & \\
\hline$n$ & 50 & 50 & 52 & NS \\
\hline$\%$ Men & 34 & 40 & 32.7 & NS \\
\hline$\%$ Women & 66 & 60 & 67.3 & NS \\
\hline Age (years) & $81.7 \pm 7.6$ & $81.7 \pm 7.7$ & $82.5 \pm 6.5$ & NS \\
\hline Weight $(\mathrm{kg})$ & $64.0 \pm 16.2$ & $65.0 \pm 13.2$ & $68.3 \pm 15.1$ & NS \\
\hline Height $(m)$ & $1.5 \pm 0.1$ & $1.5 \pm 0.1$ & $1.5 \pm 0.1$ & NS \\
\hline BMI $\left(\mathrm{kg} \mathrm{m}^{-2}\right)$ & $28.0 \pm 6.9$ & $28.8 \pm 5.5$ & $30.3 \pm 6.5$ & NS \\
\hline Waist-to-hip ratio & $0.92 \pm 0.07$ & $0.91 \pm 0.08$ & $0.89 \pm 0.06$ & NS \\
\hline $\mathrm{SBP}(\mathrm{mmHg})$ & $139.3 \pm 22.2$ & $132.6 \pm 18.4$ & $135.6 \pm 19.9$ & NS \\
\hline $\mathrm{DBP}(\mathrm{mmHg})$ & $76.4 \pm 13.1$ & $75.5 \pm 14.2$ & $75.2 \pm 12.8$ & NS \\
\hline
\end{tabular}

SD - standard deviation; T1 - population with consumption of fruit and vegetable servings $\geq 1.26$ and $<2.29$ per day; T2 - population with consumption of fruit and vegetable servings $\geq 2.29$ and $<2.79$ per day; T3 - population with consumption of fruit and vegetable servings $\geq 2.79$ and $<3.45$ per day; ANOVA - analysis of variance; BMI - body mass index; SBP - systolic blood pressure; DBP - diastolic blood pressure; NS - non-significant. 
Fruit and vegetables: conditioners of plasma homocysteine levels in the elderly

Table 2 Daily servings consumed by each tertile group (mean \pm SD)

\begin{tabular}{|c|c|c|c|c|}
\hline & T1 & $\mathrm{T} 2$ & T3 & ANCOVA \\
\hline \multicolumn{5}{|l|}{ Cereals and legumes } \\
\hline Rice and pasta & $0.38 \pm 0.25^{a}$ & $0.44 \pm 0.15^{a}$ & $0.40 \pm 0.16^{a}$ & - \\
\hline Buns and cookies & $1.07 \pm 0.80^{\mathrm{a}}$ & $1.01 \pm 0.66^{\mathrm{a}}$ & $0.93 \pm 0.81^{\mathrm{a}}$ & - \\
\hline Ready-to-eat cereal & $0.00 \pm 0.00^{\mathrm{a}}$ & $0.00 \pm 0.00^{\mathrm{a}}$ & $0.02 \pm 0.11^{\mathrm{a}}$ & _- \\
\hline Bread & $1.30 \pm 0.73^{a}$ & $1.52 \pm 0.63^{\mathrm{ab}}$ & $1.64 \pm 0.55^{\mathrm{b}}$ & - \\
\hline Flour & $0.06 \pm 0.06^{a}$ & $0.10 \pm 0.07^{\mathrm{b}}$ & $0.10 \pm 0.08^{b}$ & $P<0.05$ \\
\hline Legumes & $0.19 \pm 0.17^{\mathrm{a}}$ & $0.34 \pm 0.23^{\mathrm{b}}$ & $0.31 \pm 0.19^{b}$ & $P<0.001$ \\
\hline Total & $3.00 \pm 1.01^{\mathrm{a}}$ & $3.41 \pm 0.88^{\mathrm{ab}}$ & $3.40 \pm 0.90^{\mathrm{b}}$ & - \\
\hline DMRI & $-3.00 \pm 1.01^{\mathrm{a}}$ & $-2.59 \pm 0.80^{\mathrm{ab}}$ & $-2.60 \pm 0.90^{\mathrm{b}}$ & - \\
\hline \multicolumn{5}{|l|}{ Fruit } \\
\hline Total & $0.76 \pm 0.31^{\mathrm{a}}$ & $1.08 \pm 0.27^{\mathrm{b}}$ & $1.73 \pm 0.89^{c}$ & $P<0.001$ \\
\hline DMRI & $-1.24 \pm 0.31^{a}$ & $-0.92 \pm 0.27^{b}$ & $-0.27 \pm 0.90^{c}$ & $P<0.001$ \\
\hline \multicolumn{5}{|l|}{ Vegetables } \\
\hline Total & $1.28 \pm 0.35^{\mathrm{a}}$ & $1.75 \pm 0.28^{\mathrm{b}}$ & $2.21 \pm 0.47^{\mathrm{C}}$ & $P<0.001$ \\
\hline DMRI & $-1.72 \pm 0.35^{\mathrm{a}}$ & $-1.25 \pm 0.28^{b}$ & $-0.79 \pm 0.47^{c}$ & $P<0.001$ \\
\hline \multicolumn{5}{|l|}{ Milk products } \\
\hline Milk & $1.46 \pm 0.47^{\mathrm{a}}$ & $1.57 \pm 0.42^{\mathrm{a}}$ & $1.53 \pm 0.51^{a}$ & - \\
\hline Yoghurt & $0.53 \pm 0.41^{\mathrm{a}}$ & $0.41 \pm 0.31^{a}$ & $0.42 \pm 0.32^{\mathrm{a}}$ & - \\
\hline Semi-cured and cured cheese & $0.05 \pm 0.12^{a}$ & $0.03 \pm 0.03^{\mathrm{a}}$ & $0.06 \pm 0.08^{a}$ & - \\
\hline Fresh cheese & $0.08 \pm 0.12^{a}$ & $0.08 \pm 0.13^{a}$ & $0.08 \pm 0.12^{a}$ & - \\
\hline Total & $2.12 \pm 0.66^{\mathrm{a}}$ & $2.10 \pm 0.56^{\mathrm{a}}$ & $2.08 \pm 0.72^{a}$ & - \\
\hline DMRI & $-0.88 \pm 0.66^{a}$ & $-0.90 \pm 0.56^{\mathrm{a}}$ & $-0.92 \pm 0.72^{a}$ & - \\
\hline \multicolumn{5}{|l|}{ Meat, fish and eggs } \\
\hline Eggs & $0.31 \pm 0.20^{a}$ & $0.34 \pm 0.23^{a}$ & $0.31 \pm 0.17^{a}$ & - \\
\hline Meat & $0.58 \pm 0.22^{\mathrm{a}}$ & $0.81 \pm 0.27^{b}$ & $0.94 \pm 0.36^{\mathrm{c}}$ & $P<0.001$ \\
\hline Fish & $0.25 \pm 0.12^{a}$ & $0.34 \pm 0.15^{\mathrm{b}}$ & $0.39 \pm 0.21^{\mathrm{b}}$ & $P<0.01$ \\
\hline Total & $1.15 \pm 0.31^{\mathrm{a}}$ & $1.49 \pm 0.36^{\mathrm{b}}$ & $1.65 \pm 0.36^{\mathrm{c}}$ & $P<0.001$ \\
\hline DMRI & $-0.85 \pm 0.31^{\mathrm{a}}$ & $-0.51 \pm 0.36^{b}$ & $-0.35 \pm 0.36^{c}$ & $P<0.001$ \\
\hline Nuts & $0.00 \pm 0.00^{\mathrm{a}}$ & $0.01 \pm 0.04^{\mathrm{a}}$ & $0.04 \pm 0.16^{\mathrm{a}}$ & - \\
\hline
\end{tabular}

SD - standard deviation; T1 - population with consumption of fruit and vegetable servings $\geq 1.26$ and $<2.29$ per day; T2 - population with consumption of fruit and vegetable servings $\geq 2.29$ and $<2.79$ per day; T3 - population with consumption of fruit and vegetable servings $\geq 2.79$ and $<3.45$ per day; ANCOVA - analysis of covariance; DMRI - difference from the minimum recommended intake.

Different letters indicate significant differences between groups (Newman-Keuls test): $P<0.05$.

between energy intake and theoretical energy expenditure was taken into account.

The intake of energy $(P<0.001)$, carbohydrates $(P<0.01)$ and proteins $(P<0.001)$ increased with the consumption of fruit and vegetables. However, ANCOVA showed that this increase in protein consumption was not due to the extra intake of fruit and vegetables, but rather to the associated increased intake of fish and meats because the significance disappeared after correcting for the underestimation of food intake, plus the differences in the consumption of meat and fish between the three groups.

The intake of fibre increased with consumption of fruit and vegetables $(r=0.6839, P<0.001)$ (Table 3$)$. No significant differences were seen between the tertile groups with respect to energy and lipid profiles when the data were corrected for the underestimation of food intake, and for fish and meat intake (Table 3).

The recommended intakes of vitamins and minerals were better covered by the diets of $\mathrm{T} 2$ and $\mathrm{T} 3$ subjects (Table 4). Table 5 shows that T3 subjects had significantly higher serum and erythrocyte folate levels than T1 and T2 subjects $(P<0.05)$. A positive correlation was found between the consumption of fruit and vegetables and serum folate $(r=0.2665, P<0.01)$ and erythrocyte folate levels $(r=0.2034, P<0.05)$, and a negative correlation with t-Hcys $(r=-0.2493, P<0.01)$. An inverse correlation was found between t-Hcys and serum cyanocobalamin $(r=-0.2066, P<0.05)$ and serum folate levels $(r=-0.2971, P<0.001)$.

\section{Discussion}

The mean consumption of fruit and vegetables was $2.95 \pm 0.92$ servings day ${ }^{-1}$, similar to that seen in other groups of elderly people ${ }^{32}$, but lower than that recommended (a minimum of five servings daily) ${ }^{15}$. Although this recommendation was not met, this study shows that a greater intake of fruit and vegetables is associated with more healthy food habits in general via a positive correlation with a greater intake of cereals, legumes, nuts and fish (typical foods of the Mediterranean diet) (Table 2) and with the reduced consumption of sweet foods ${ }^{33,34}$. Independently of its nutritional components, the Mediterranean diet has frequently been reported to help prevent $\mathrm{CVD}^{35,36}$, as well as other degenerative diseases such as cancer ${ }^{37}$ and mental deterioration $^{38}$, and to increase longevity ${ }^{34}$.

A greater intake of fruits and vegetables was also associated with better coverage of the recommended intakes of many nutrients, some of which are thought to exercise a 
Table 3 Intake of energy and macronutrients, energy and lipid profiles in the different tertile groups (mean \pm SD)

\begin{tabular}{lcccc}
\hline & T1 & T2 & T3 & ANOVA \\
\hline Daily intake & & & & \\
$\quad$ Energy (kJ) & $6782.2 \pm 1178.9^{\mathrm{a}}$ & $7644.8 \pm 1229.3^{\mathrm{b}}$ & $8124.2 \pm 1167.6^{\mathrm{c}}$ & $P<0.001$ \\
Proteins (g) & $59.4 \pm 8.4^{\mathrm{a}}$ & $71.0 \pm 10.3^{\mathrm{b}}$ & $76.7 \pm 11.7^{\mathrm{c}^{\mathrm{b}}}$ & $P<0.001$ \\
Carbohydrates (g) & $183.5 \pm 30.3^{\mathrm{a}}$ & $206.1 \pm 31.4^{\mathrm{b}}$ & $217.0 \pm 32.3^{\mathrm{b}}$ & $P<0.01$ \\
Lipids (g) & $74.3 \pm 20.1^{\mathrm{a}}$ & $83.0 \pm 19.3^{\mathrm{b}}$ & $88.9 \pm 19.7^{\mathrm{b}}$ & $\mathrm{NS}$ \\
$\quad$ Cholesterol (mg) & $227.1 \pm 68.9^{\mathrm{a}}$ & $263.0 \pm 74.3^{\mathrm{b}}$ & $270.8 \pm 55.9^{\mathrm{c}}$ & $\mathrm{NS}$ \\
$\quad$ Fibre (g) & $11.3 \pm 2.7^{\mathrm{a}}$ & $16.4 \pm 3.8^{\mathrm{b}}$ & $18.5 \pm 3.8^{\mathrm{b}}$ & $P<0.001$ \\
Caloric profile (\% energy) & & & & \\
$\quad$ Proteins & $14.9 \pm 1.9^{\mathrm{a}}$ & $15.7 \pm 1.6^{\mathrm{b}}$ & $15.9 \pm 1.8^{\mathrm{b}}$ & $\mathrm{P}<0.001$ \\
$\quad$ Carbohydrates & $43.0 \pm 4.8^{\mathrm{a}}$ & $42.7 \pm 3.9^{\mathrm{a}}$ & $42.3 \pm 4.5^{\mathrm{a}}$ & $\mathrm{NS}$ \\
Lipids & $40.9 \pm 5.6^{\mathrm{a}}$ & $40.7 \pm 4.4^{\mathrm{a}}$ & $41.1 \pm 4.9^{\mathrm{a}}$ & $\mathrm{NS}$ \\
Lipid profile (\% energy) & & & & $\mathrm{NS}$ \\
$\quad$ SFA & $12.0 \pm 2.0^{\mathrm{a}}$ & $12.1 \pm 1.4^{\mathrm{a}}$ & $12.0 \pm 1.8^{\mathrm{a}}$ & $\mathrm{NS}$ \\
MUFA & $17.9 \pm 4.6^{\mathrm{a}}$ & $17.8 \pm 2.9^{\mathrm{a}}$ & $18.4 \pm 3.9^{\mathrm{a}}$ & $\mathrm{NS}$ \\
PUFA & $6.2 \pm 1.6^{\mathrm{a}}$ & $6.4 \pm 1.7^{\mathrm{a}}$ & $6.6 \pm 1.3^{\mathrm{a}}$ & \\
Discrepancy EI - EE & $631.8 \pm 1363.3^{\mathrm{a}}$ & $83.37 \pm 1157.7^{\mathrm{b}}$ & $360.1 \pm 1358.3^{\mathrm{b}}$ & $P<0.001$ \\
$\quad$ KJ & $7.35 \pm 17.26^{\mathrm{a}}$ & $-1.71 \pm 15.51^{\mathrm{b}}$ & $-6.06 \pm 17.99^{\mathrm{b}}$ & $P<0.001$ \\
\% & &
\end{tabular}

SD - standard deviation; T1 - population with consumption of fruit and vegetable servings $\geq 1.26$ and $<2.29$ per day; T2 - population with consumption of fruit and vegetable servings $\geq 2.29$ and $<2.79$ per day; T3 - population with consumption of fruit and vegetable servings $\geq 2.79$ and $<3.45$. per day; ANOVA - analysis of variance; SFA - saturated fatty acids; MUFA - monounsaturated fatty acids; PUFA - polyunsaturated fatty acids; El - energy intake $\left(\mathrm{kJ}\right.$ day ${ }^{-1}$ ); EE - estimated energy expenditure $\left(\mathrm{kJ} \mathrm{day}^{-1}\right)$; NS - non siginificant.

Different letters indicate significant differences between groups (Newman-Keuls test): $P<0.05$.

cardioprotective effect (fibre, antioxidant vitamins (C and A), vitamins $\mathrm{B}_{1}, \mathrm{~B}_{2}, \mathrm{~B}_{6}, \mathrm{~B}_{12}$ and folic acid), and of phosphorus and zinc (Table 4). Numerous epidemiological studies have shown an association between the consumption of fibre and a lower risk of $\mathrm{CVD}^{39}$. The main cardioprotective effect of fibre is owed to its characteristic cholesterol-lowering agents $^{40}$. Others suggest that diets rich in fibre may lower blood pressure ${ }^{41}$. However, in the present study, no relationship was seen between the intake of fruit and vegetables and plasma lipid levels or blood pressure.

Many authors have reported that antioxidant vitamins provide protection against $\mathrm{CVD}^{2,42}$. The antioxidants and polyphenols in fruit and vegetables (vitamin C, carotenoids and flavonoids) prevent the oxidation of plasma lipids ${ }^{11,42}$, exert an anti-inflammatory effect on the endothelium and improve endothelial function ${ }^{11,42}$. This appears to be especially true of vitamin $C^{43}$.

Other studies have shown the important role played by minerals such as phosphorus, magnesium and zinc in the regulation of blood pressure and in reducing the risk of myocardial infarction ${ }^{44}$. There are even studies that suggest that these minerals might modulate the extent of atherogenesis $^{45}$. These nutrients may therefore be very important in the prevention of CVD - and in the present study their intake was higher in subjects who consumed more fruit and vegetables.

Table 4 Contribution of the diet towards the coverage of recommended intakes for micronutrients in the different tertile groups (mean $\pm \mathrm{SD}$ )

\begin{tabular}{|c|c|c|c|c|}
\hline & $\mathrm{T} 1$ & $\mathrm{~T} 2$ & T3 & ANCOVA \\
\hline Vitamin $\mathrm{B}_{1} \mathrm{CRI}(\%)$ & $78.8 \pm 18.2^{a}$ & $98.1 \pm 17.7^{b}$ & $111.6 \pm 16.4^{c}$ & $P<0.001$ \\
\hline Vitamin $\mathrm{B}_{2} \mathrm{CRI}(\%)$ & $96.3 \pm 22.1^{a}$ & $104.8 \pm 17.8^{b}$ & $111.7 \pm 19.6^{b}$ & NS \\
\hline Niacin CRI (\%) & $129.8 \pm 18.9^{a}$ & $163.6 \pm 25.4^{b}$ & $184.3 \pm 30.2^{c}$ & $P<0.001$ \\
\hline Vitamin $\mathrm{B}_{6} \mathrm{CRI}(\%)$ & $66.6 \pm 13.2^{a}$ & $83.8 \pm 12.8^{b}$ & $94.1 \pm 14.0^{c}$ & $P<0.001$ \\
\hline Folic acid CRI (\%) & $32.3 \pm 8.4^{a}$ & $44.2 \pm 8.1^{b}$ & $49.5 \pm 11.3^{c}$ & $P<0.001$ \\
\hline Vitamin $\mathrm{B}_{12} \mathrm{CRI}(\%)$ & $102.0 \pm 32.0^{a}$ & $123.3 \pm 41.5^{\mathrm{b}}$ & $133.4 \pm 52.6^{b}$ & $P<0.05$ \\
\hline Vitamin C CRI (\%) & $141.4 \pm 45.1^{a}$ & $175.4 \pm 38.5^{b}$ & $230.4 \pm 64.1^{c}$ & $P<0.001$ \\
\hline Vitamin A CRI (\%) & $85.2 \pm 27.7^{a}$ & $95.4 \pm 25.3^{a}$ & $114.6 \pm 42.9^{b}$ & $P<0.01$ \\
\hline Vitamin D CRI (\%) & $18.8 \pm 13.3^{a}$ & $19.8 \pm 16.2^{a}$ & $21.0 \pm 20.1^{a}$ & NS \\
\hline Vitamin E CRI (\%) & $81.1 \pm 30.6^{a}$ & $91.6 \pm 41.0^{a}$ & $95.2 \pm 28.5^{a}$ & NS \\
\hline Phosphorus CRI (\%) & $121.5 \pm 21.1^{a}$ & $148.3 \pm 20.9^{b}$ & $156.7 \pm 25.8^{b}$ & $P<0.001$ \\
\hline Magnesium CRI (\%) & $55.1 \pm 9.0^{a}$ & $67.9 \pm 8.8^{b}$ & $73.8 \pm 10.9^{c}$ & $P<0.001$ \\
\hline Calcium CRI (\%) & $56.2 \pm 13.3^{a}$ & $59.8 \pm 10.8^{a}$ & $62.0 \pm 14.5^{\mathrm{a}}$ & NS \\
\hline Zinc CRI (\%) & $52.5 \pm 12.0^{a}$ & $60.2 \pm 10.6^{b}$ & $66.1 \pm 10.1^{c}$ & $P<0.001$ \\
\hline Iron CRI (\%) & $79.2 \pm 15.4^{a}$ & $99.4 \pm 16.6^{b}$ & $107.9 \pm 15.6^{c}$ & $P<0.001$ \\
\hline
\end{tabular}

SD - standard deviation; T1 - population with consumption of fruit and vegetable servings $\geq 1.26$ and $<2.29$ per day; T2 - population with consumption of fruit and vegetable servings $\geq 2.29$ and $<2.79$ per day; T3 - population with consumption of fruit and vegetable servings $\geq 2.79$ and $<3.45$ per day; ANCOVA - analysis of covariance; CRI - coverage of recommended intake; NS-non siginificant. Different letters indicate significant differences between groups (Newman-Keuls test): $P<0.05$. 
Table 5 Biochemical data for the different tertile groups (mean \pm SD)

\begin{tabular}{|c|c|c|c|c|c|}
\hline & T1 & T2 & T3 & ANOVA & SCT \\
\hline$\alpha$-EGR (vitamin $\mathrm{B}_{2}$ ) & $1.04 \pm 0.14^{\mathrm{a}}$ & $1.09 \pm 0.14^{a}$ & $1.08 \pm 0.15^{a}$ & NS & - \\
\hline Vitamin $\mathrm{B}_{6}\left(\mathrm{nmol} \mathrm{I} \mathrm{I}^{-1}\right)$ & $53.2 \pm 40.0^{\mathrm{a}}$ & $40.5 \pm 20.6^{\mathrm{a}}$ & $49.7 \pm 59.2^{\mathrm{a}}$ & NS & - \\
\hline Vitamin $\mathrm{B}_{12}\left(\mathrm{pmol} \mathrm{I}^{-1}\right)$ & $389.9 \pm 284.5^{\mathrm{a}}$ & $385.5 \pm 298.7^{a}$ & $314.5 \pm 158.0^{\mathrm{a}}$ & NS & - \\
\hline Serum folate $\left(\mathrm{nmol} \mathrm{I}^{-1}\right)$ & $13.9 \pm 6.1^{\mathrm{a}}$ & 13. $9 \pm 5.4^{\mathrm{a}}$ & $17.7 \pm 6.0^{\mathrm{b}}$ & $P<0.01$ & $r=0.2665^{\star *}$ \\
\hline Erythrocyte folate $\left(\mathrm{nmol} \mathrm{I}^{-1}\right)$ & $593.1 \pm 258.3$ & $588.5 \pm 256.1^{a}$ & $879.0 \pm 812.1^{\mathrm{b}}$ & $P<0.01$ & $r=0.2034^{*}$ \\
\hline Homocysteine $\left(\mu \mathrm{mol} \mathrm{I}{ }^{-1}\right)$ & $19.0 \pm 5.1^{\mathrm{a}}$ & $17.3 \pm 5.6^{\mathrm{ab}}$ & $16.1 \pm 6.1^{\mathrm{b}}$ & NS & $r=-0.2493^{\star *}$ \\
\hline Cholesterol $\left(\mathrm{nmol} \mathrm{I}^{-1}\right.$ & $5.03 \pm 1.04^{\mathrm{a}}$ & $5.07 \pm 1.05^{\mathrm{a}}$ & $5.27 \pm 1.06^{\mathrm{a}}$ & NS & - \\
\hline HDL-cholesterol (nmol I $\left.{ }^{-1}\right)$ & $1.30 \pm 0.36^{\mathrm{a}}$ & $1.27 \pm 0.33^{\mathrm{a}}$ & $1.33 \pm 0.27^{\mathrm{a}}$ & NS & - \\
\hline LDL-cholesterol (nmol I-1) & $3.14 \pm 0.83^{a}$ & $3.24 \pm 0.83^{a}$ & $3.37 \pm 0.89^{a}$ & NS & - \\
\hline Triglycerides $\left(\mathrm{nmol} \mathrm{I}^{-1}\right)$ & $1.29 \pm 0.60^{a}$ & $1.21 \pm 0.41^{\mathrm{a}}$ & $1.25 \pm 0.62^{a}$ & NS & - \\
\hline
\end{tabular}

SD - standard deviation; T1 - population with consumption of fruit and vegetable servings $\geq 1.26$ and $<2.29$ per day; T2 - population with consumption of fruit and vegetable servings $\geq 2.29$ and $<2.79$ per day; T3 - population with consumption of fruit and vegetable servings $\geq 2.79$ and $<3.45$ per day; ANOVA - analysis of variance; SCT - Spearman correlation test ( $\left.{ }^{\star \star} P<0.01,{ }^{*} P<0.05\right)$; $\alpha$-EGR - coefficient of activation of erythrocyte glutathione reductase; HDL - high-density lipoprotein; LDL - low-density lipoprotein; NS-non siginificant.

Different letters indicate significant differences between groups (Newman - Keuls test): $P<0.05$.

No significant differences were found between T1, T2 and T3 subjects with respect to serum lipid levels. However, some authors report a beneficial effect of diets rich in fruits and vegetables with respect to plasma lipid metabolism, with reductions in triglyceride, total cholesterol and LDL-cholesterol levels ${ }^{8}$, and an increase in HDL-cholesterol ${ }^{46}$. However, the majority of these studies took their subjects from the adult or general population rather than from the elderly sub-population. In the elderly, the conclusions to be drawn might be different since some studies on this age group suggest that high total and LDL-cholesterol levels may no longer be a risk for CVD, and may even be beneficial $^{47}$.

A high t-Hcys level is an independent risk factor for CVD; this compound promotes the oxidation of the endothelium and inhibits the production of nitric oxide, thus favouring the development and progress of atherosclerosis ${ }^{48}$. The present results show that $\mathrm{t}$-Hcys levels are reduced as fruit and vegetable consumption increases. At the same time, serum and erythrocyte folate levels are increased. An inverse relationship was also seen between t-Hcys and serum cyanocobalamin and serum folate levels. Other studies $^{2,5}$ have reported similar results and suggest that diets rich in foods containing group $\mathrm{B}$ vitamins (fruits, vegetables, legumes, etc.) are associated with lower t-Hcys levels.

In conclusion, the present study shows that higher intakes of fruit and vegetables are associated with better food habits and favour the intake of vitamins and minerals with probable cardioprotective effects - in particular the reduction of t-Hcys levels. Encouraging members of the elderly population to consume more of these foods could have a beneficial influence on their health and nutritional status.

\section{Acknowledgements}

This work was financed by Unilever Netherlands via the Universidad-Empresa project 138/2000.

\section{References}

1 World Health Organization (WHO). Cardiovascular Disease: Prevention and Control. Global Strategy on Diet, Physical Activity and Health. Geneva: WHO, 2003.

2 Samman S, Sivarajah G, Man JC, Ahmad ZI, Petocz P, Caterson ID. A mixed fruit and vegetable concentrate increases plasma antioxidant vitamins and folate and lowers plasma homocysteine in men. Journal of Nutrition 2003; 133: $2188-93$

3 Suliman ME, Stenvinkel $\mathrm{P}$, Barany $\mathrm{P}$, Heimburger $\mathrm{O}$, Anderstam B, Lindholm B. Hyperhomocysteinemia and its relationship to cardiovascular disease in ESRD: influence of hypoalbuminemia, malnutrition, inflammation, and diabetes mellitus. American Journal of Kidney Disease 2003; 41(3 Suppl 1): S89-95.

4 Ullegaddi R, Powers HJ, Gariballa SE. B-group vitamin supplementation mitigates oxidative damage after acute ischaemic stroke. Clinical Science (London) 2004; 107: 477-84.

5 Ortega RM, Jimenez A, Andres P, Faci M, Lolo JM, Lozano MC, et al. Homocysteine levels in elderly Spanish people: influence of pyridoxine, vitamin B12 and folic acid intakes. Journal of Nutritional Health and Aging 2002; 6: 69-71.

6 Vrentzos GE, Papadakis JA, Malliaraki N, Zacharis EA, Mazokopakis E, Margioris A, et al. Diet, serum homocysteine levels and ischaemic heart disease in a Mediterranean population. British Journal of Nutrition 2004; 91: 1013-9.

7 Gao X, Bermudez OI, Tucker KL. Plasma C-reactive protein and homocysteine concentrations are related to frequent fruit and vegetable intake in Hispanic and non-Hispanic white elders. Journal of Nutrition 2004; 134: 913-8.

8 Djousse L, Arnett DK, Coon H, Province MA, Moore LL, Ellison RC. Fruit and vegetable consumption and LDL cholesterol: the National Heart, Lung, and Blood Institute Family Heart Study. American Journal of Clinical Nutrition 2004; 79: 213-7.

9 Miura K, Greenland P, Stamler J, Liu K, Daviglus ML, Nakagawa $H$. Relation of vegetable, fruit, and meat intake to 7-year blood pressure change in middle-aged men: the Chicago Western Electric Study. American Journal of Epidemiology 2004; 159: 572-80.

10 Brown AA, Hu FB. Dietary modulation of endothelial function: implications for cardiovascular disease. American Journal of Clinical Nutrition 2001; 73: 673-86.

11 Rissanen TH, Voutilainen S, Virtanen JK, Venho B, Vanharanta M, Mursu J, et al. Low intake of fruits, berries and vegetables is associated with excess mortality in men: the Kuopio Ischaemic Heart Disease Risk Factor (KIHD) Study. Journal of Nutrition 2003; 133: 199-204. 
12 Genkinger JM, Platz EA, Hoffman SC, Comstock GW, Helzlsouer KJ. Fruit, vegetable, and antioxidant intake and all-cause cancer and cardiovascular disease mortality in a community-dwelling population in Washington County, Maryland. American Journal of Epidemiology 2004; 160: 1223-33.

13 Fletcher AE, Breeze E, Shetty PS. Antioxidant vitamins and mortality in older persons: findings from the nutrition addon study to the Medical Research Council trial of assessment and management of older people in the community. American Journal of Clinical Nutrition 2003; 78: 999-1010.

14 Maisey S, Loughridge J, Southon S, Fulcher R. Variation in food group and nutrient intake with day of the week in an elderly population. British Journal of Nutrition 1995; 73: 359-73.

15 Perea JM, Navia B. Nutrición del paciente de edad avanzada. In: Requejo AM, Ortega RM, eds. Nutriguia. Manual de Nutrición Clínica en Atención Primaria. Madrid: Editorial Complutense, 2000; 72-82.

16 Instituto de Nutrición (CSIC). Tablas de Composición de Alimentos. Madrid: CSIC, 1994.

17 Moreiras O, Carbajal A, Cabrera M. Tablas de Composición de Alimentos. Madrid: Piramide, 1998.

18 Departamento de Nutrición. Ingestas de Energía y Nutrientes Recomendadas para la Población Española. Madrid: Universidad Complutense de Madrid, 1999.

19 Ortega RM. Necesidades nutricionales del anciano. Bases para establecer unas ingestiones recomendadas adecuadas a este grupo de población. Formación Continuede de Nutrición y Obesidad 2002; 5: 163-77.

20 World Health Organization (WHO). Energy and Protein Requirements. Report of a Joint Food and Agriculture Organization/WHO/United Nations University Expert Consultation. WHO Technical Report Series No. 724. Geneva: WHO, 1985; 1-206.

21 Dallosso HM, Morgan K, Bassey EJ, Ebrahim SB, Fentem PH, Arie TH. Levels of customary physical activity among the old and the very old living at home. Journal of Epidemiology and Community Health 1988; 42: 121-7.

22 Johnson RK, Goran MI, Poehlman ET. Correlates of overand underreporting of energy intake in healthy older men and women. American Journal of Clinical Nutrition 1994; 59: $1286-90$.

23 World Health Organization (WHO). Methodology of Nutritional Surveillance. Report of a Joint Food and Agriculture Organization/WHO/United Nations University Expert Consultation. WHO Technical Report Series No. 53. Geneva: WHO, 1976; 20-60.

24 Vuilleumier JP, Keller HE, Rettenmaier R, Hunziker F. Clinical chemical methods for the routine assessment of the vitamin status in human populations. Part II: the water-soluble vitamins B1, B2 and B6. International Journal for Vitamin and Nutrition Research 1983; 53: 359-70.

25 Ubbink JB, Serfontein WJ, de Villiers LS. Stability of pyridoxal-5-phosphate semicarbazone: applications in plasma vitamin B6 analysis and population surveys of vitamin B6 nutritional status. Journal of Chromatography 1985; 342: 277-84.

26 Lindenbaum J. Status of laboratory testing in the diagnosis of megaloblastic anemia. Blood 1983; 61: 624-7.

27 Bucolo G, David H. Quantitative determination of serum triglycerides by the use of enzymes. Clinical Chemistry 1973; 19: $476-82$.

28 Allain CC, Poon LS, Chan CS, Richmond W, Fu PC. Enzymatic determination of total serum cholesterol. Clinical Chemistry 1974; 20: 470-5.

29 Friedewald WT, Levy RI, Fredrickson DS. Estimation of the concentration of low-density lipoprotein cholesterol in plasma, without use of the preparative ultracentrifuge. Clinical Chemistry 1972; 18: 499-502.

30 Turnell DC, Cooper JD. Rapid assay for amino acids in serum or urine by pre-column derivatization and reversed-phase liquid chromatography. Clinical Chemistry 1982; 28: 527-31.

31 Frohlich ED, Grim C, Labarthe DR. Recommendations for human blood pressure determination by sphygmomanometers: report of a special task force appointed by the Steering Committee American Heart Association. Hypertension 1988; 11: 209-22.

32 Requejo AM, Ortega RM, Robles F, Navia B, Faci M, Aparicio A. Influence of nutrition on cognitive function in a group of elderly, independently living people. European Journal of Clinical Nutrition 2003; 57: S54-7.

33 Kok FJ, Kromhout D. Atherosclerosis epidemiological studies on the health effects of a Mediterranean diet. European Journal of Nutrition 2004; 43: I2-I5.

34 Trichopoulou A. Traditional Mediterranean diet and longevity in the elderly: a review. Public Health Nutrition 2004; 7: 943-7.

35 Schroder H, Marrugat J, Vila J, Covas MI, Elosua R. Adherence to the traditional Mediterranean diet is inversely associated with body mass index and obesity in a Spanish population. Journal of Nutrition 2004; 134: 3355-61.

36 Lasheras C, Huerta JM, Gonzalez S, Prada M, Braga S, Fernandez S, et al. Diet score is associated with plasma homocysteine in a healthy institutionalised elderly population. Nutrition Metabolism and Cardiovascular Disease 2003; 13: 384-90

37 La Vecchia C. Mediterranean diet and cancer. Public Health Nutrition 2004; 7: 965-8.

38 Solfrizzi V, Panza F, Capurso A. The role of diet in cognitive decline. Journal of Neural Transmission 2003; 110: 95-110.

39 Pereira MA, O'Reilly E, Augustsson K, Fraser GE, Goldbourt U, Heitmann BL, et al. Dietary fiber and risk of coronary heart disease: a pooled analysis of cohort studies. Archives of Internal Medicine 2004; 164: 370-6.

40 Mia MA, Siddiqui MN, Haque MS, Islam MN, Rukunzzaman M, Deb K. Dietary fibre and coronary heart disease. Mymensingh Medical Journal 2002; 11: 133-5.

41 He J, Streiffer RH, Muntner P, Krousel-Wood MA, Whelton PK. Effect of dietary fiber intake on blood pressure: a randomized, double-blind, placebo-controlled trial. Journal of Hypertension 2004; 22: 73-80.

42 Kiefer I, Prock P, Lawrence C, Wise J, Bieger W, Bayer P, et al. Supplementation with mixed fruit and vegetable juice concentrates increased serum antioxidants and folate in healthy adults. Journal of the American College of Nutrition 2004; 23: 205-11

43 Sanchez-Moreno C, Dashe JF, Scott T, Thaler D, Folstein MF, Martin A. Decreased levels of plasma vitamin C and increased concentrations of inflammatory and oxidative stress markers after stroke. Stroke 2004; 35: 163-8.

44 Zhao L, Stamler J, Yan LL, Zhou B, Wu Y, Liu K, et al.; INTERMAP Research Group. Blood pressure differences between northern and southern Chinese: role of dietary factors: the International Study on Macronutrients and Blood Pressure. Hypertension 2004; 43: 1332-7.

45 Alissa EM, Bahijri SM, Lamb DJ, Ferns GA. The effects of coadministration of dietary copper and zinc supplements on atherosclerosis, antioxidant enzymes and indices of lipid peroxidation in the cholesterol-fed rabbit. International Journal of Experimental Pathology 2004; 85: 265-75.

46 Kurowska EM, Spence JD, Jordan J, Wetmore S, Freeman DJ, Piche LA, et al. HDL-cholesterol-raising effect of orange juice in subjects with hypercholesterolemia. American Journal of Clinical Nutrition 2000; 72: 1095-100.

47 Karlamangla AS, Singer BH, Reuben DB, Seeman TE. Increases in serum non-high-density lipoprotein cholesterol may be beneficial in some high-functioning older adults: MacArthur studies of successful aging. Journal of the American Geriatrics Society 2004; 52: 487-94.

48 Das UN. Nutritional deficiencies and the prevalence of syndrome X in South Asians. Nutrition 2002; 18: 282. 